\title{
Streptosporangium corrugation sp.nov., an Actinomycete with Some Unusual Morphological Features
}

\author{
S. T. WILLIAMS AND G. P. SHARPLES \\ Botany Department, University of Liverpool, Liverpool L69 3BX, United Kingdom
}

\begin{abstract}
The micromorphology, ultrastructure, and cell wall composition of an actinomycete isolated from beach sand were studied. On the basis of its cell wall composition and some of its morphological features, it was placed in the genus Streptosporangium. It differed from other members of this genus by producing rather ill-defined sporangia containing thick-walled, ridged spores together with short chains of similar spores. This organism is regarded as belonging to a new species, for which we propose the name Streptosporangium corrugatum. The type strain of this species is E90 (NCIB 11120).
\end{abstract}

Genera of the order Actinomycetales are distinguished primarily by their spore morphology and the chemical composition of their walls $(6$, $11,18)$. Although there are differences between the various classification schemes proposed, all actinomycetes which form their spores within sporangia or vesicles and have meso-2,6-diaminopimelic acid in their walls are placed in the family Actinoplanaceae. Genera within this family can be divided into two groups (6). Those in the first group (Actinoplanes, Ampullariella, and Dactylosporangium) form sparse aerial mycelium and have glycine and meso-diaminopimelic acid in their cell walls. The second group (Planomonospora, Planobispora, Spirillospora, and Streptosporangium) have a well developed aerial mycelium and lack glycine in their cell walls.

We have examined the morphology and cell wall composition of an isolate which belongs to the family Actinoplanaceae but which has several morphological characteristics not previously observed in other members of this family. The purpose of this paper is to report the results of our studies on this isolate.

\section{MATERIALS AND METHODS}

Bacterial strain. Strain E90 was isolated from beach sand (pH 7.8) at Freshfield, Lancashire, United Kingdom. It was detected on dilution plates prepared with starch-casein medium containing antifungal antibiotics (24). Most actinomycetes on the plates were micromonosporas (22), and E90 accounted for less than $1 \%$ of the total colonies.

Cultural characteristics. Cultures were first grown on oatmeal agar at a range of temperatures to determine the temperature most suitable for subsequent experiments. Optimum growth occurred at 25 C.

The isolate was then grown on a variety of media (see Table 1) for 21 days. The extent of growth of substrate and aerial mycelium and presence of spor- ing structures were noted. Colors of aerial growth, substrate growth, and soluble pigments were determined using the color chart of Prauser (17).

Morphology and fine structure. Most aerial growth and spore formation occurred on oatmeal agar, and this medium was used for studies of morphology. Observations by light microscopy were carried out on blocks of medium removed from plate cultures after 7,14 , and 21 days of incubation.

For scanning electron microscopy, small blocks of medium with growth were removed from plates after the same periods, and these were quenched in isopentane at about $-150 \mathrm{C}$ and then freeze dried at $-60 \mathrm{C}$ in a Pearce Edwards tissue dryer for $20 \mathrm{~h}$. They were then coated under vacuum with a film of gold-palladium and examined with a Stereoscan at $20 \mathrm{kV}$.

For transmission electron microscopy, blocks of medium with growth were fixed in buffered $1 \%$ (wt/vol) osmium tetroxide for $16 \mathrm{~h}$ at room temperature, followed by a $3-\mathrm{h}$ wash in $0.5 \%$ (wt/vol) uranyl acetate. They were then dehydrated with ethanol and embedded in an epoxy resin (21). Ultrathin sections were prepared and examined with an EM6B (A.E.I. Ltd.) electron microscope at 60 $\mathrm{kV}$.

Cell wall composition. Cells for chemical analyses were grown in static flask cultures at room temperature in a medium containing $0.1 \%(\mathrm{wt} / \mathrm{vol})$ yeast extract (Oxoid), $0.2 \%$ (wt/vol) Casamino Acids (Difco), $0.1 \%$ (wt/vol) beef extract (Oxoid), and $0.2 \%$ (wt/vol) glucose, at $\mathrm{pH}$ 7.0. Cells were harvested, washed, and freeze dried. A crude cell wall preparation was obtained by crushing cells in an $\mathrm{X}$ press (L.K.B) and centrifuging to remove whole cells. A pellet of crude walls was suspended in $0.2 \mathrm{M}$ phosphate buffer containing $0.5 \mathrm{mg}$ of Pronase (B.D.H.) per $\mathrm{ml}$ and incubated at $37 \mathrm{C}$ for $16 \mathrm{~h}$. Treated walls were washed three times with distilled water and freeze dried.

Walls were examined for reducing sugars and amino acids by the methods of Bowden (2) and for isomers of diaminopimelic acid by the procedures of Hoare and Work (9). They were examined for the presence of lipid characteristic of Nocardia by the chromatographic procedure of Mordarska et al. (14). 
TABLE 1. Cultural characteristics of Streptosporangium corrugatum ${ }^{a}$

\begin{tabular}{|c|c|c|c|c|}
\hline \multirow{2}{*}{ Medium } & \multicolumn{2}{|c|}{ Aerial mycelium } & \multicolumn{2}{|c|}{ Substrate mycelium } \\
\hline & Amount & Color & Amount & Color \\
\hline Yeast extract-malt extract (20) & - & & ++ & Co6a (pale buff) \\
\hline Glycerol-asparagine $(20)$ & - & & + & Co5a (pale buff) \\
\hline Inorganic salts-starch (20) & - & & + & Co5a (pale buff) \\
\hline Nutrient agar (Oxoid) & - & & ++ & Co6a (pale buff) \\
\hline Oatmeal (20) & ++ & WI (white) & +++ & Co5b (pale buff) \\
\hline Oatmeal $+1 \%$ yeast extract & + & WI (white) & +++ & Co5b (pale buff) \\
\hline Potato-carrot (7) & - & & ++ & Co6a (pale buff) \\
\hline Starch-casein (10) & - & & ++ & Co5b (pale buff) \\
\hline
\end{tabular}

${ }^{a}$ Color codes from chart of Prauser (17). Symbols: - , growth absent; + , growth sparse; ++ , growth moderate; +++ , growth abundant.

\section{RESULTS}

Cultural characteristics. On all media used, substrate growth of the isolate was pale buff and lacked soluble pigment. Aerial growth was detected only on oatmeal and oatmealyeast extract media and in both cases was white. The cultural characteristics are given in Table 1.

Morphology and fine structure. Examination by light microscopy showed that sporing structures occurred on aerial growth only. Two types of structure, club-shaped and varioussized spherical bodies, could be distinguished (Fig. 1). The distinction between these structures was also clear in scanning electron micrographs of aerial growth (Fig. 2). In 7- and 14day-old cultures, the various sized spherical bodies were common; the club-shaped structures were infrequent except in 21-day-old cultures.

At higher magnifications, the spherical structures appeared to be covered by a wrinkled envelope; contents of these structures were not visible, but the undulations of the envelope suggested that spores might be present within (Fig. 3). Disruption of some of these structures was achieved by flooding cultures with water and preparing them without freeze drying. Removal of the outer envelope revealed ridged spores in a coiled chain (Fig. 4). Club-shaped structures developed at the tips of aerial hyphae; their length ranged from 3.5 to $8.0 \mu \mathrm{m}$, and their width ranged from 0.75 to $1.00 \mu \mathrm{m}$. At first, their surface was smooth (Fig. 5), but it became wrinkled as spores developed (Fig. 6). As the club-shaped structures matured, partial or complete removal of their outer, wrinkled envelop revealed chains of three to eight spores which were prominently ridged (Fig. 7, 8, 9). Their length was 0.8 to $1.0 \mu \mathrm{m}$ and their breadth was 0.6 to $0.7 \mu \mathrm{m}$. Ridges were mostly longitudinal with annular ones between ad- jacent spores. The form of these spores was, therefore, the same as those found inside the spherical bodies.

Ultrathin sections of spore chains showed that they developed within an envelope which also contained moderately electron-dense extrasporal material (Fig. 10). Sections of spherical bodies showed variously orientated hyphae surrounded by a thin envelope which appeared to be continuous with the outer sheath of the parent hypha (Fig. 11). Mature spores developed thickened walls (up to $150 \mathrm{~nm}$ ) in which ridges were sometimes visible (Fig. 12, 13). Two layers could sometimes be distinguished in the thickened spore wall.

The stages in spore formation and the release for both sporing structures are summarized in Fig. 14.

Cell wall composition. The cell wall of our isolate contained meso-diaminopimelic acid but lacked arabinose and glycine. It contained only traces of galactose, rhamnose, and mannose. No lipid characteristic of Nocardia was detected. Its cell wall composition was, therefore, similar to that of members of the genera Planomonospora, Spirillospora, and Streptosporangium (Table 2).

\section{DISCUSSION}

The genus Streptosporangium (4) contains actinomycetes bearing sporangia on their aerial mycelium. The spores are nonmotile and may be formed in chains as well as in sporangia, as in $S$. bovinum (3), $S$. roseum (4), and $S$. viridogriseum (16). Sporangia range in diameter from 7 to $40 \mu \mathrm{m}$, and spores are usually oval or spherical with diameters from 0.2 to $2.0 \mu \mathrm{m}$. Studies on the spore formation process in Streptosporangium have shown that spores in both sporangia and chains form in essentially the same way $(13,19)$. In both cases, spores are produced by fragmentation of a hypha within 

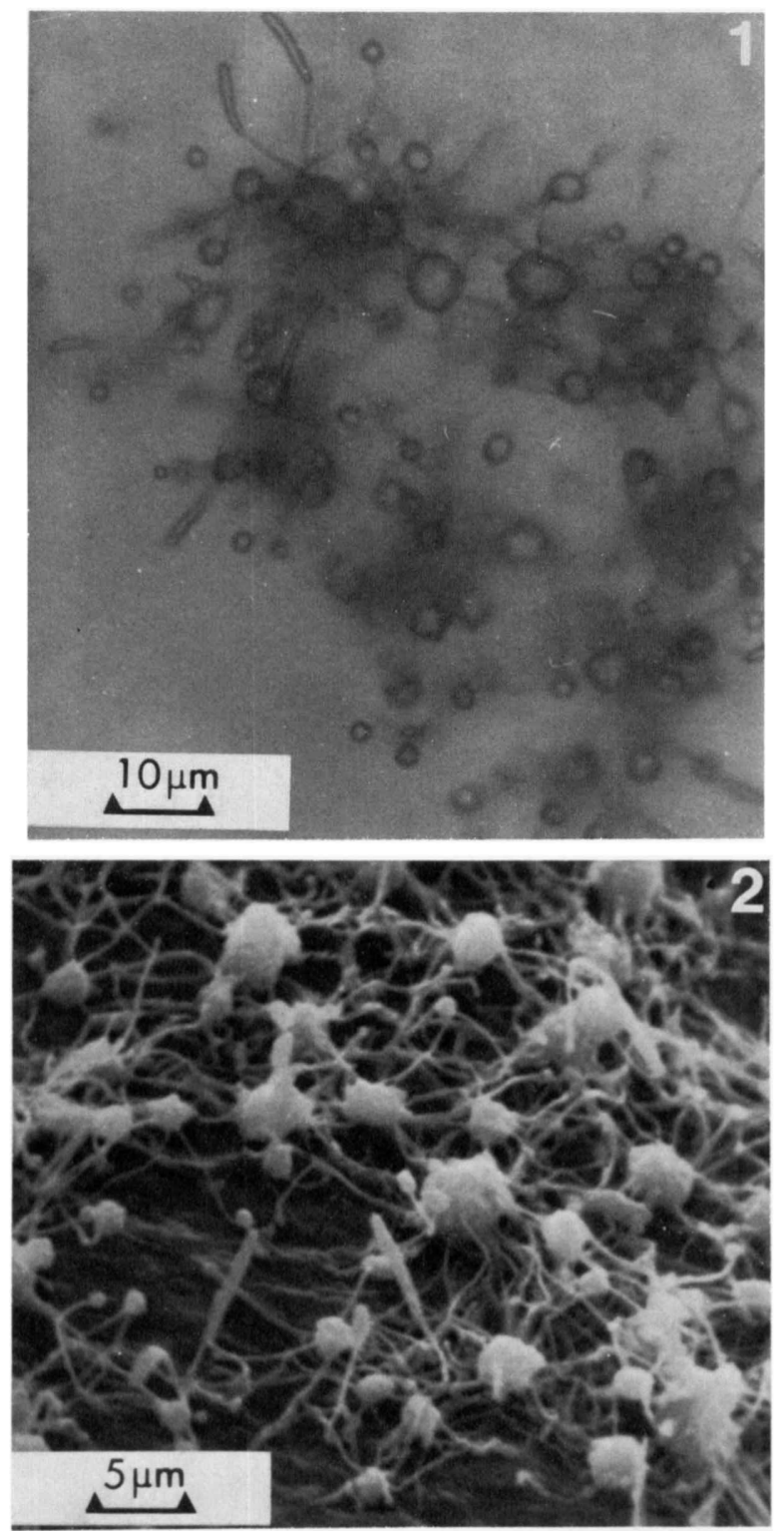

FIG. 1. Light micrograph of sporing aerial mycelium.

FIG. 2. Scanning electron micrograph of sporing aerial mycelium.

its sheath, which either expands to form the sporangial envelope or remains around the spore chain. Therefore, truly endogenous spore formation does not occur, and it has been suggested that the term "spore vesicle" should replace "sporangium" $(5,19)$.

The morphology and spore development of the organism studied here were similar in many respects to those of Streptosporangium species. There were, however, some important differences. The vesicles were rather irregular in shape, variable in size, and smaller than those in most streptosporangia. Coiling of the sporogenous hypha within its expanded sheath was also less regular than usual. Formation of club-shaped structures by streptosporangia has not been reported, but these may be regarded as analogous to the spore chains observed in some species. Thick-walled spores with longitudinal and annular ridges have not been observed in Streptosporangium or in any other actinomycete. Endospores of Thermoactino- 
WILLIAMS AND SHARPLES
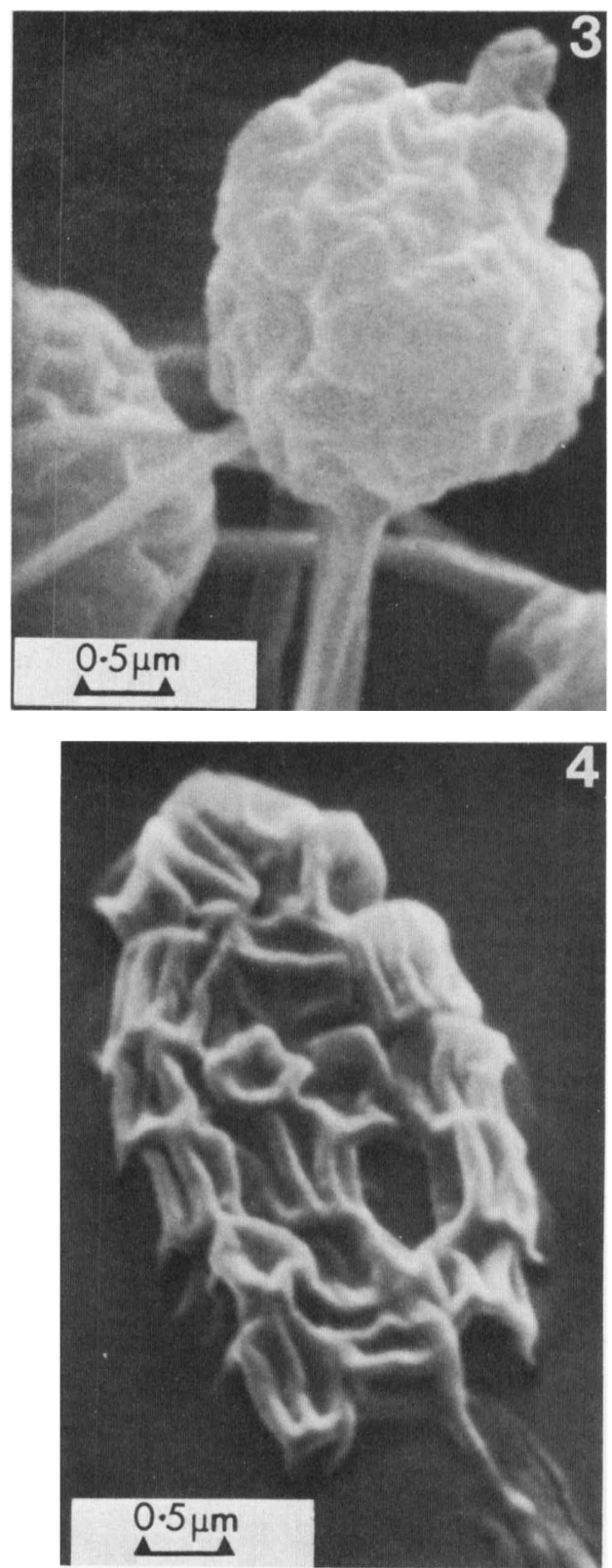

FIG. 3. Spherical body with outer envelope in place (scanning electron micrograph).

FIG. 4. Coiled chain of ridged spores in spherical body after removal of outer envelope (scanning electron micrograph).

myces vulgaris and Actinobifida dichotomica have a ridged outer coat, but internally they resemble the endospores of Bacillus and Clostridium $(8,23)$.

The cell wall composition of this organism corresponds to type III of Lechevalier and Lech-
INT. J. Syst. Bacteriol.
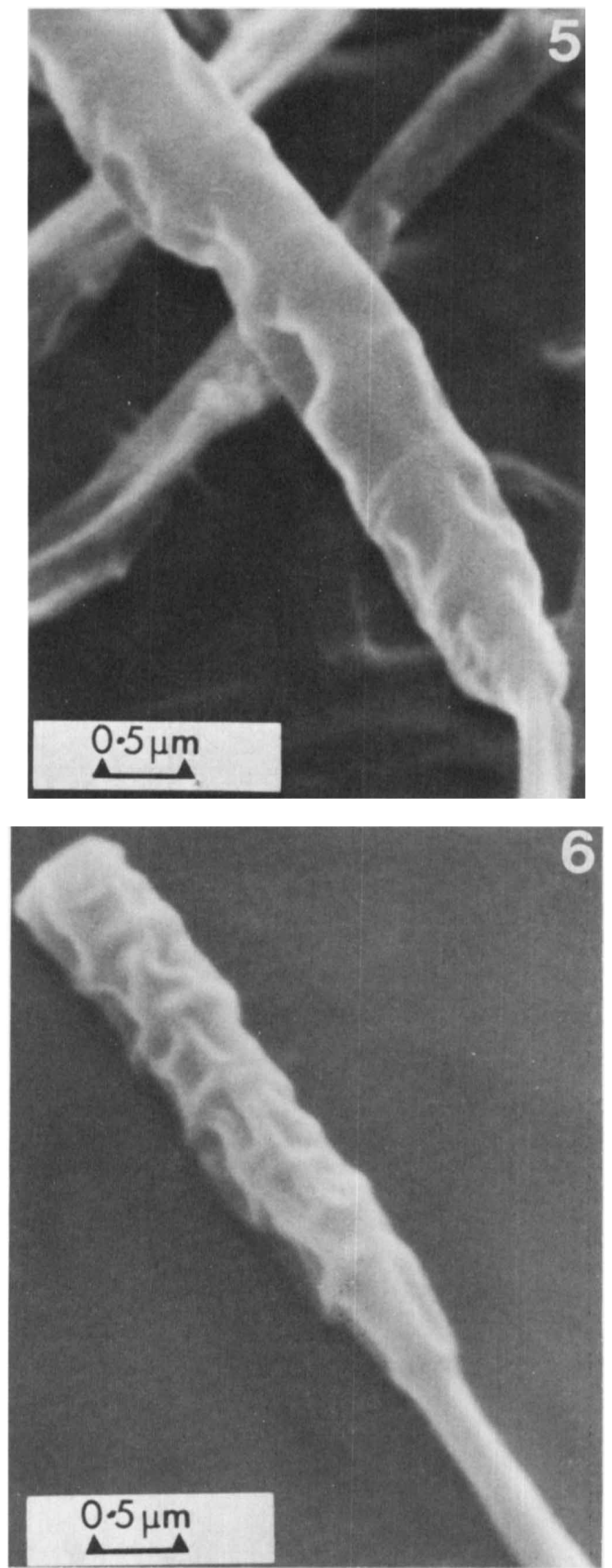

FIG. 5. Young club-shaped structure (scanning electron micrograph).

FIG. 6. Club-shaped structure with envelope wrinkled over developing spores (scanning electron micrograph).

evalier (11) with meso-diaminopimelic acid but no glycine, arabinose, or galactose. Most Streptosporangium species have type III cell walls, 

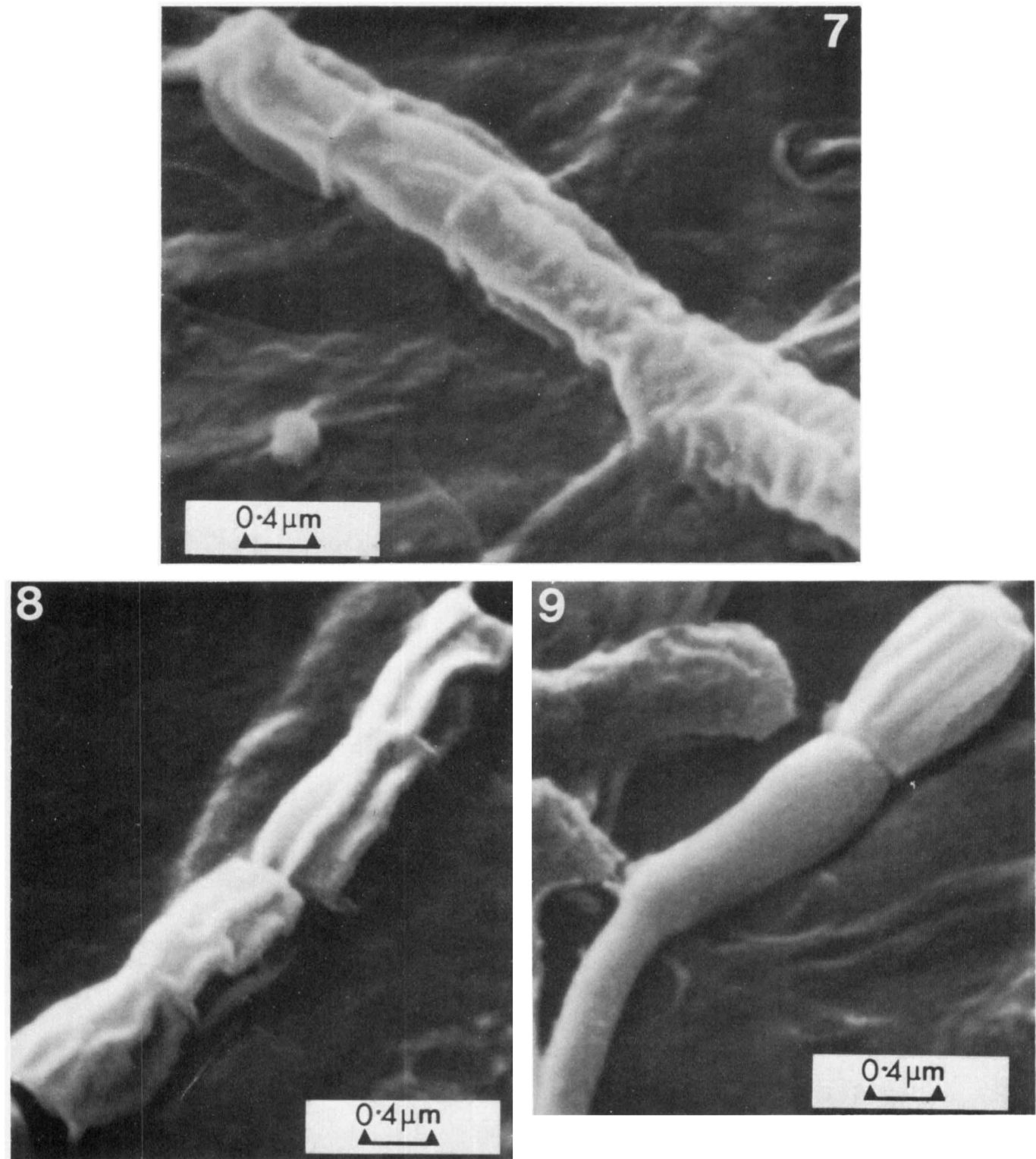

FIG. 7. Partial disruption of sheath revealing ridged spores (scanning electron micrograph).

FIG. 8. Chain of ridged spores (scanning electron micrograph).

Fig. 9. Single spore attached to hypha which bore club-shaped structure (scanning electron micrograph).

but some contain glycine and fall into type II (1, 12).

Species of Streptosporangium have been distinguished primarily by differences in color of aerial mycelium, substrate mycelium, and soluble pigments; little information on their physiological characteristics is available. The cultural features of our isolate resemble those of Streptosporangium album (15), which has white aerial mycelium and a pale yellow reverse but which produces a yellow soluble pigment.

We regard our isolate as belonging to a new species, for which we propose the name Streptosporangium corrugatum ( $\mathrm{L}$. adj. corrugatus ridged).

Morphology and ultrastructure. Stable, gram-positive mycelium is formed with aerial hyphae bearing globose vesicles (1.0 to $5.0 \mu \mathrm{m}$ diameter) and club-shaped structures (3.5 to 8.0 $\mu \mathrm{m}$ by 0.75 to $1.00 \mu \mathrm{m})$. Vesicles contain coiled 

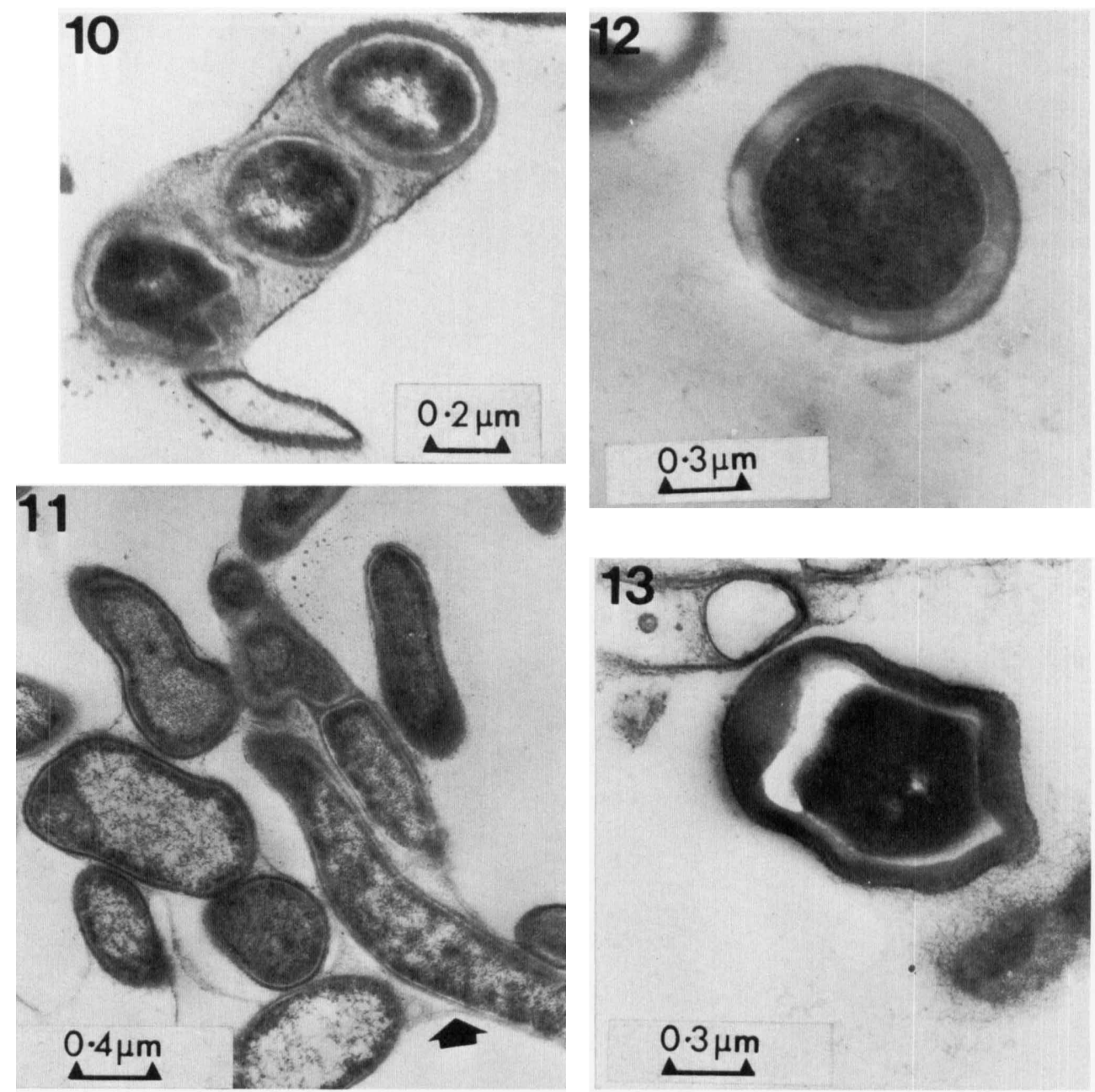

FIG. 10. Section of developing spore chain showing extrasporal material.

Fig. 11. Section of developing spherical body showing continuity of envelope (arrow) with parent hypha. FiG. 12. Section of spore with thickened wall.

FIG. 13. Section of mature spore with thickened, ridged wall.
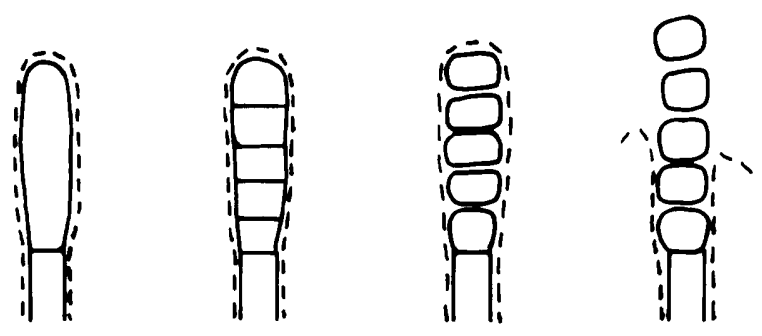

A

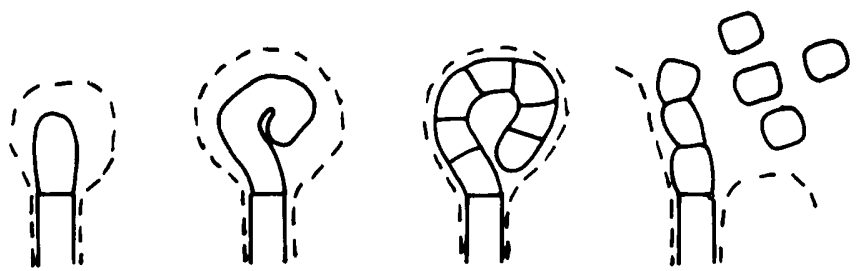

B

FIG. 14. Stages in formation of spherical and club-shaped structures. 
TABLE 2. Cell wall composition of Streptosporangium corrugatum compared with those of other members ${ }^{a}$ of the family Actinoplanaceae

\begin{tabular}{|c|c|c|c|c|c|}
\hline \multirow{3}{*}{ Taxon } & \multicolumn{5}{|c|}{ Cell wall components } \\
\hline & \multicolumn{2}{|c|}{ Diaminopimelic acid } & \multirow{2}{*}{ Galactose } & \multirow{2}{*}{ Arabinose } & \multirow{2}{*}{ Glycine } \\
\hline & $\mathbf{L L}$ & Meso & & & \\
\hline Streptosporangium corrugatum & - & + & Trace & - & - \\
\hline Streptosporangium spp. & - & + & - & - & - \\
\hline Planomonospora & - & + & - & - & - \\
\hline Spirillospora & - & + & - & - & - \\
\hline Actinoplanes & - & + & - & - & + \\
\hline Ampullariella & - & + & - & - & + \\
\hline Dactylosporangium & - & + & - & - & + \\
\hline
\end{tabular}

${ }^{a}$ Data from Becker and Lechevalier. (1), Lechevalier et al. (12), and Lechevalier and Lechevalier (11).

chains of about 20 spores, and club-shaped structures contain three to eight spores. Spores from both structures are nonmotile, 0.8 to $1.0 \mu \mathrm{m}$ by 0.6 to $0.7 \mu \mathrm{m}$, with prominent longitudinal ridges and terminal annular ridges. Spore walls become considerably thickened, reaching $150 \mathrm{~nm}$.

Color. Aerial mycelium and sporing structures are white, the reverse side of the colony is pale buff, and no soluble pigment is produced.

Cell walls. Neso-diaminopimelic acid is present but glycine, arabinose, and galactose are absent (type III of Lechevalier and Lechevalier [11]).

Type strain. The type strain, E90, has been deposited in the National Collection of Industrial Bacteria, Aberdeen, Scotland, as NCIB 11120. Since the species description is based on a single strain, the type strain, it also serves as the description of the type strain.

\section{ACKNOWLEDGMENTS}

We acknowledge a research grant from the Science Research Council which supported part of this work. The kind assistance of M. Goodfellow and G. Bowden is gratefully acknowledged.

\section{REPRINT REQUESTS}

Address reprint requests to: Dr. S. T. Williams, Botany Department, Liverpool University, Liverpool L69 3BX, England.

\section{LITERATURE CITED}

1. Becker, B., and H. A. Lechevalier. 1965. Chemical composition of cell wall preparations from strains of various form-genera of aerobic actinomycetes. Appl. Microbiol. 13:236-243.

2. Bowden, G. H. 1969. The components of the cell walls and extracellular slime of four strains of Staphylococcus salivarius isolated from human dental plaque. Arch. Oral Biol. 14:685-697.

3. Chaves Batista, A., S. K. Shome, and J. America De Lima. 1963. Streptosporangium bovinum sp. nov. from cattles hoofs. Dermatol. Trop. Ecol. Geogr. 2:49.

4. Couch, J. N. 1955. A new genus and family of the
Actinomycetales, with a revision of the genus Actinoplanes. J. Elisha Mitchell Sci. Soc. 71:148-155.

5. Cross, T. 1970. The diversity of bacterial spores. J. Appl. Bacteriol. 33:95-102.

6. Cross, T., and M. Goodfellow. 1973. Taxonomy and classification of the actinomycetes, p. 11-112. In G. Sykes and F. A. Skinner (ed.), The Actinomycetales: characteristics and practical importance. Academic Press Inc., New York.

7. Cross, T., M. P. Lechevalier, and H. A. Lechevalier. 1963. A new genus of the Actinomycetales: Microellobosporia gen. nov. J. Gen. Microbiol. 31:421-429.

8. Cross, T., P. D. Walker, and G. W. Gould. 1968. Thermophilic actinomycetes producing resistant endospores. Nature (London) 220:352-354.

9. Hoare, D. S., and E. Work. 1957. The stereo-isomers of $\alpha, \epsilon$-diaminopimelic acid. 2. Their distribution in the bacterial order Actinomycetales and in certain Eubacteriales. Biochem. J. 65:441-447.

10. Küster, E., and S. T. Williams. 1964. Selection of media for isolation of streptomycetes. Nature (London) 202:928-929.

11. Lechevalier, M. P., and H. A. Lechevalier. 1970. Chemical composition as a criterion in the classification of aerobic actinomycetes. Int. J. Syst. Bacteriol. 20:435-443.

12. Lechevalier, H. A., M. P. Lechevalier, and B. Becker. 1966. Comparison of the chemical composition of cellwalls of nocardiae with that of other aerobic actinomycetes. Int. J. Syst. Bacteriol. 16:151-160.

13. Lechevalier, H. A., M. P. Lechevalier, and P. E. Holbert. 1966. Electron microscopic observation of the sporangial structure of strains of Actinoplanaceae. J. Bacteriol. 92:1228-1235.

14. Mordarska, H., M. Mordarski, and M. Goodfellow. 1972. Chemotaxonomic characters and classification of some nocardioform bacteria. J. Gen. Microbiol. 71:77-87.

15. Nonomura, H., and Y. Ohara. 1960. Distribution of the actinomycetes in soil. $\mathrm{V}$. The isolation and classification of the genus Streptosporangium. J. Ferment. Technol. 38:405-409.

16. Okuda, T., T. Furumai, E. Watanabe, Y. Okugawa, and S. Kimura. 1966. Actinoplanaceae antibiotics. II. Studies of sporoviridin. 2. Taxonomic study of the sporoviridin producing microorganism: Streptosporangium viridogriseum nov. sp. J. Antibiot. Ser. A 19:121.

17. Prauser, H. 1964. Aptness and application of colour codes for exact description of colours of streptomycetes. Z. Allg. Mikrobiol. 4:95-98.

18. Prauser, H. 1970. Characters and genera arrangement 
in the Actinomycetales, p. 407-418. In H. Prauser (ed.), The Actinomycetales. Gustav Fisher, Jena.

19. Sharples, G. P., S. T. Williams, and R. M. Bradshaw. 1974. Spore formation in the Actinoplanaceae (Actinomycetales). Arch. Mikrobiol. 101:9-20.

20. Shirling, E. B., and D. Gottlieb. Methods for characterization of Streptomyces species. Int. J. Syst. Bacteriol. 16:313-340.

21. Spurr, A. R. 1969. A low-viscosity epoxy resin embedding medium for electron microscopy. J. Ultrastruct.
Res. 26:31-43.

22. Watson, E. T., and S. T. Williams. 1974. Studies on the ecology of actinomycetes in soil. VII. Actinomycetes in a coastal sand belt. Soil Biol. Biochem. 6:43-52.

23. Williams, S. T. 1970. Further investigations of actinomycetes by scanning electron microscopy. J. Gen. Microbiol. 62:67-74.

24. Williams, S. T., and F. L. Davies. 1965. Use of antibiotics for selective isolation and enumeration of actinomycetes in soil. J. Gen. Microbiol. 38:251-261. 